\title{
TRENDS IN POULTRY CONSUMPTION AFTER POLAND'S ACCESSION TO THE EUROPEAN UNION
}

\author{
Marzena Trajer, $\mathrm{MSc}^{1}$; Martyn Mieczkowski, $\mathrm{MSc}^{2}$
}

National Support Centre for Agriculture

\begin{abstract}
The poultry industry is one of the most rapidly developing sectors of the national agriculture, and Poland is the largest poultry producer in the European Union. Since Poland's accession to the European Union, the two main factors determining the development of the poultry industry in Poland have been export demand and the growing domestic consumption. The aim of this article was to analyse the changes in the balance sheet of poultry consumption in Poland in the context of conditions of the poultry market and to analyse the impact of changes in red meat consumption on changes in the dynamics of poultry consumption.
\end{abstract}

Keywords: poultry consumption, poultry, production, foreign sales

\section{INTRODUCTION}

Poland is a traditional poultry producer. For many years now, rearing of poultry, i.e. first and foremost birds of the Gallus domesticus species (mainly broiler chickens) and turkeys, as well as geese, ducks and helmeted guinea fowls, has been the most intensive area of animal production (Trajer, 2018). Before Poland's accession to the European Union, the national poultry industry carried out a number of modernisation activities in order to adjust to competition on the single EU market. As a result of the investments made before accession to the European Union, a modern production infrastructure was created in Poland - poultry houses, hatcheries, slaughterhouses and processing facilities which comply with high standards. In the pre-accession period, a number of measures were taken in order to improve the qual- ity of poultry meat. This aim was achieved owing to breeding development in the scope of improvement of meat content in poultry and optimisation of nutrition. At the same time, introduction of high sanitary standards at every production stage resulted in the quality parameters of Polish meat being very good (Mieczkowski, 2015). This process was facilitated and accelerated by production investments with the use of preferential loans for live weight producers as part of adjustment efforts. Implementation of modern solutions led to an improvement in the effectiveness of fattening and lower production costs, accompanied by implementation of high veterinary and sanitary standards (Mieczkowski, 2013). Poland's accession to the European Union resulted in adoption by Poland of all legal regulations of the EU as regards trade arrangements and provisions regarding bird welfare and the natural environment (Mieczkowski, 2015).

\footnotetext{
${ }^{1}$ Corresponding author: Karolkowa 30, 01-207 Warsaw, Poland, marzena.trajer@kowr.gov.pl, +4822 3767311

${ }^{2}$ Corresponding author: Karolkowa 30, 01-207 Warsaw, Poland, martyn.mieczkowski@kowr.gov.pl, +4822 3767017
} 
Proceedings of the 2018 International Scientific Conference 'Economic Sciences for Agribusiness and Rural Economy' No 2, Warsaw, 7-8 June 2018, pp. 154-160

\section{MATERIAL AND METHODS}

The aim of the study was to present trends in poultry consumption in Poland after the accession to the European Union against the background of changing market conditions with changes in consumer eating habits. The study uses an analysis of time series derived from the database of National Support Centre for Agriculture (KOWR), data of the subject literature as well as data from the Central Statistical Office (GUS), United States Department of Agriculture USDA) and the Organisation for Economic Co-operation and Development (OECD). The results of the study were presented in a descriptive and graphical form.

\section{CONSUMPTION OF POULTRY IN THE EUROPEAN UNION AND WORLDWIDE}

In 2017, in EU-28 the average poultry consumption amounted to $23.8 \mathrm{~kg}$ per capita and was $0.4 \%$ lower than in 2016. The share of poultry in total meat consumption amounted to nearly $35 \%$ just like in 2016
(European Commission, 2018). According to the estimates of the Food and Agriculture Organization of the United Nations (FAO) and the Organisation for Economic Cooperation and Development (OECD), in 2017 the global poultry consumption amounted to $13.86 \mathrm{~kg}$ per capita and was $0.5 \%$ greater than in the preceding year. In economically advanced countries in 2017 poultry consumption reached the level of $29.65 \mathrm{~kg}$ per capita, while in developing countries it amounted to $10.25 \mathrm{~kg}$ (IERiGŻ-PIB et al., 2018). The world largest consumers of poultry meat per capita in 2017 were: Israel $(56.9 \mathrm{~kg})$, USA $(48.3 \mathrm{~kg})$, Australia (46.3 kg), Saudi Arabia (46.3 kg) and Malaysia $(43.3 \mathrm{~kg})$ (OECD database). Poland is a country with one of the greatest levels of poultry consumption in the European Union after Portugal, Spain, Ireland and Hungary. A statistical Polish citizen consumes approximately $7 \mathrm{~kg}$ of poultry more than the EU average and approximately $16 \mathrm{~kg}$ more than the global average (Polska Ziemia - Biuletyn informacyjny, 2018).

In 2017 world production of broiler meat (according to the data of the United States Department

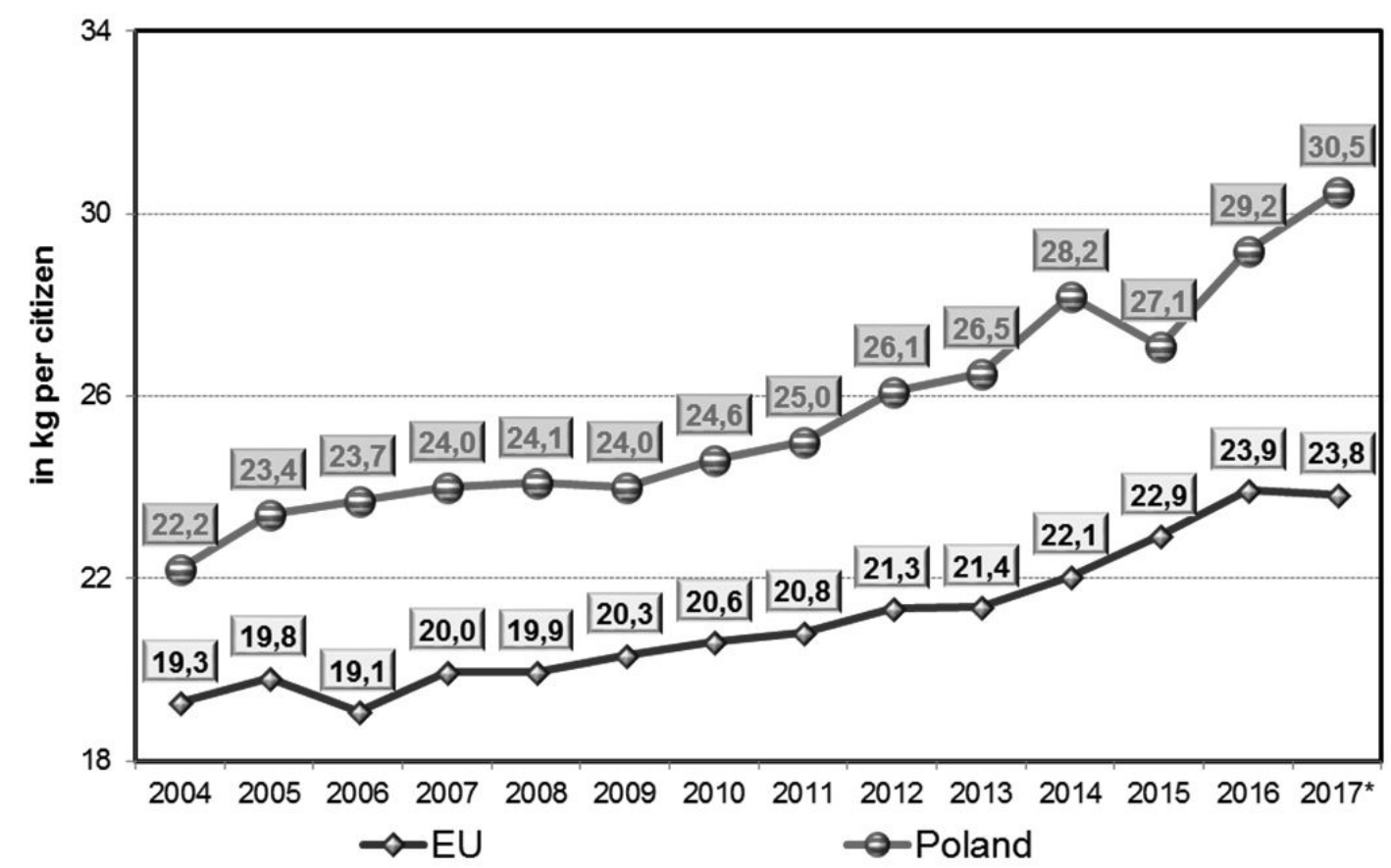

*Estimate of the Institute of Agricultural and Food Economics - National Research Institute and the EC

Figure 1. Balance sheet of poultry consumption in the EU and in Poland per capita

Source: own study based on the data of Statistics Poland (GUS) and the Institute of Agricultural and Food Economics - National Research Institute as well as European Commission (2018). 
of Agriculture) increased by $1.7 \%$ to 90.7 million tonnes. World leaders in the production of broilers remain USA, Brazil, EU and China, whose total share in global production is over $60 \%$. In 2018, a further increase in global production is expected to reach 92.5 million tonnes. Production will increase, among others in Brazil and the United States (2\% each), as well as in the EU (by 1.4\%) and China (by 1\%). Forecasts of production growth result mainly from the growing consumption demand in the world (USDA, 2018).

\section{MARKET CONDITIONS OF TRENDS IN POULTRY CONSUMPTION}

Development of the poultry industry in Poland is characterised by dynamic growth of the most important parameters of supply and demand, i.e. increasing production, export and consumption of poultry. Production of live poultry in Poland has been continually increasing since 1994, and the growth rate is significantly faster than in other Member States (Trajer, 2018). The most dynamic increase in poultry production was noted after Poland's accession to the European Union. In the years 2004-2017, the production of poultry in Poland (in live weight) grew from 1.3 million tonnes to an estimated 3.4 million tonnes (2.4 million tonnes carcass weight). Such a high rate of growth of poultry production was stimulated by the rising export demand and the increasing domestic consumption resulting from the price competitiveness of poultry as compared with red meat. According to the data of Statistics Poland (GUS), in 2017 the retail price index for poultry amounted to $2.1 \%$, whereas in the case of pork and beef it amounted to 8.6 and $2.9 \%$, respectively (KOWR, 2018). The rapidly increasing poultry production resulted in a change in the structure of meat production in Poland. In 2004, the share of poultry in the total meat production in Poland amounted to $26 \%$, while the share of pork and beef together with veal amounted to 57 and $10 \%$, respectively. In 2016, the share of poultry meat in the production structure increased to $45 \%$. At the same time, the share of pork dropped to $38 \%$, while the share of beef and veal remained at $10 \%$.

The rapid increase in poultry production in Poland was a consequence of the following factors: a short production cycle (especially of broilers), the growing demand on the domestic and foreign market, the feed conversion rate being lower than in the case of red meat (beef and pork) (Stańko and Mikuła, 2017).

The fast-growing domestic production significantly exceeds the increase in consumption, which creates the need to manage the resulting market surpluses on foreign markets. In the last few years, Poland became a leader in poultrny production in the EU (2.4 million tonnes carcass weight.) as well as one of the larger exporters of poultry (Dybowski, 2016). The main competitors of Poland in 2016 in terms of poultry production are: the United Kingdom (1.8 million tonnes carcass weight), France (1.6 million tonnes) as well as Spain and Germany (1.5 million tonnes each).

Poland's accession to the European Union granted Polish poultry producers access to nearly 460 million of relatively wealthy consumers, which enabled a rapid increase in export in subsequent years (Mieczkowski, 2015). In the years 2004-2017, the volume of foreign sales of Polish poultry grew nearly tenfold, from 142 thousand tonnes to an estimated 1,375 thousand tonnes.

The dynamic increase of export resulted from the need to manage the growing production surpluses exceeding the domestic demand on foreign markets. The absolute growth of consumption and the rate thereof were lower than those of production, which created the need to manage the increasing production on foreign markets (Stańko and Mikuła, 2017). The success in foreign trade in the presented decade was doubtless connected with the high level of price competitiveness of Polish poultry on the European market, the increasing demand of EU consumers and adjustment of the offered products to the needs of foreign customers. The highest $(50 \%)$ increase in export of Polish poultry was noted in 2005. Such a great increase in the volume of export of poultry from Poland was possible due to the restrictions imposed by the European Union on purchase of this type of meat from third markets due to the global epidemic of avian influenza. By utilising the resulting supply gap, Polish producers strengthened their position on the Community market. The commercial contacts with EU customers established at the time formed the basis for cooperation in subsequent years (Mieczkowski, 2015). 


\section{INCREASE IN POULTRY CONSUMPTION IN POLAND}

Apart from the increase in export, after Poland's accession to the European Union the development of the Polish poultry industry was stimulated by growing domestic consumption. The increase in poultry consumption was a result of changes in the dietary habits of Polish people in connection with the rising popularity of healthy eating (Mieczkowski, 2015). Poultry meat is a source of complete animal protein. According to the model recommended by the FAO/ $\mathrm{WHO}$, the biological value of chicken meat is equivalent to that of milk protein. Nutrition-wise, poultry is superior to pork and beef as it contains more crude protein and less connective tissue, in particular collagen. Poultry is easily digestible and has a lower energy value because not only does it contain less fat, but it is also rich in unsaturated fatty acids. It is also a good source of minerals such as potassium, calcium, phosphorus, sodium and iron (Nowak and Trziszka, 2010). The delicate structure of poultry meat makes it easy to digest, which in combination with the wide variety of products and ease of preparation for consumption generates increasing interest of consumers (Mieczkowski, 2013). In the years 2004-2017, the changes in dietary preferences of Polish consumers and the price ratios between poultry and red meat stimulated an increase in poultry consumption, with a greater decrease in beef consumption and changing but relatively stable consumption of pork. The greatest increase in the balance sheet of poultry consumption was noted in the first two years of Poland's membership in the European Union (2004-2005), which was first and foremost a consequence of the growing retail prices of pork and beef. As a consequence, in

Table 1. Balance sheet of meat consumption in Poland

\begin{tabular}{|c|c|c|c|c|c|c|c|}
\hline \multirow{2}{*}{ Year } & \multicolumn{5}{|c|}{ Meat consumption per capita (kg) } & \multicolumn{3}{c|}{$\begin{array}{c}\text { Share of individual types of meat in total meat } \\
\text { consumption (\%) }\end{array}$} \\
\cline { 2 - 8 } & $\begin{array}{c}\text { total (meat } \\
\text { and offal) }\end{array}$ & pork & beef & poultry & pork & beef & poultry \\
\hline 2003 & 72.1 & 41.2 & 5.8 & 19.7 & 57.1 & 8.0 & 27.3 \\
\hline 2004 & 71.8 & 39.1 & 5.3 & 22.2 & 54.5 & 7.4 & 30.9 \\
\hline 2005 & 71.2 & 39.0 & 3.9 & 23.4 & 54.8 & 5.5 & 32.9 \\
\hline 2006 & 74.3 & 41.4 & 4.5 & 23.7 & 55.7 & 6.1 & 31.9 \\
\hline 2007 & 77.6 & 43.6 & 4.0 & 24.0 & 56.2 & 5.2 & 30.9 \\
\hline 2008 & 75.3 & 42.7 & 3.8 & 24.1 & 56.7 & 5.0 & 32.0 \\
\hline 2009 & 75.0 & 42.4 & 3.6 & 24.0 & 56.5 & 4.8 & 32.0 \\
\hline 2010 & 73.7 & 42.2 & 2.4 & 24.6 & 57.3 & 3.3 & 33.4 \\
\hline 2011 & 73.4 & 42.5 & 2.1 & 25.0 & 57.9 & 2.9 & 34.1 \\
\hline 2012 & 71.0 & 39.2 & 1.6 & 26.1 & 55.2 & 2.3 & 36.8 \\
\hline 2013 & 67.5 & 35.5 & 1.5 & 26.5 & 52.6 & 2.2 & 39.3 \\
\hline 2014 & 73.6 & 39.1 & 1.6 & 28.2 & 53.1 & 2.2 & 38.3 \\
\hline 2015 & 75.0 & 41.4 & 1.2 & 27.1 & 55.2 & 1.6 & 36.1 \\
\hline 2016 & 77.6 & 40.8 & 2.1 & 29.2 & 52.6 & 2.7 & 37.6 \\
\hline $2017 *$ & 78.5 & 40.5 & 2.2 & 30.5 & 51.6 & 2.8 & 38.9 \\
\hline
\end{tabular}

* Estimate of the Institute of Agricultural and Food Economics - National Research Institute.

Source: own study based on the data of Statistics Poland (GUS) and the Institute of Agricultural and Food Economics - National Research Institute. 
Proceedings of the 2018 International Scientific Conference 'Economic Sciences for Agribusiness and Rural Economy' No 2, Warsaw, 7-8 June 2018, pp. 154-160

the years 2003-2005 the consumption of poultry increased by $19 \%$, from 19.7 to $23.4 \mathrm{~kg}$ per capita.

In the years 2006-2007, the increase in poultry consumption was smaller than in the first two years of Poland's membership in the European Union. This was mainly a result of the increase in price competitiveness of pork. In 2007, the consumption of poultry in Poland amounted to $24 \mathrm{~kg}$ per capita, compared with $23.7 \mathrm{~kg}$ in 2006 . In the years 2008-2009, the consumption of poultry in Poland was stable and remained at a level of approximately $24 \mathrm{~kg}$ per capita. The slowdown of the increase in poultry consumption was connected with the decrease in total demand for food as a result of the financial crisis which started in 2008 (Mieczkowski, 2015). After three years of stabilisation in domestic consumption, in the years 2010-2013 there was a rapid growth in consumption of poultry - up to $26.5 \mathrm{~kg}$ per capita. The growth of poultry consumption was driven by increased use thereof by mass caterers as well as the relatively slow rate of increase of retail prices compared with red meat, among other things. On the other hand, in 2013 there was a moderate increase in the retail prices of red meat, while the retail prices of poultry remained stable. The above-mentioned factors contributed towards maintenance of the price competitiveness of poultry as compared with red meat, which was the main factor stimulating growth in consumption. The increase in poultry consumption noted in the years 2010-2013 did not manage to fully compensate for the reduction in red meat consumption, which led to a decrease in total meat consumption to $67.5 \mathrm{~kg}$ per capita. In 2014, there was a recovery in the domestic demand for meat, driven by the decrease in retail prices of poultry and red meat. These factors led to a $6 \%$ increase in the balance sheet of poultry consumption in Poland, up to $28.2 \mathrm{~kg}$ per capita. The rise in poultry consumption was accompanied by growth in red meat consumption, which resulted in a $9 \%$ increase in the total balance sheet meat consumption to $73.6 \mathrm{~kg}$ per capita.

After a temporary decrease in poultry consumption in Poland in 2015, in the following year there was a further increase in domestic demand.

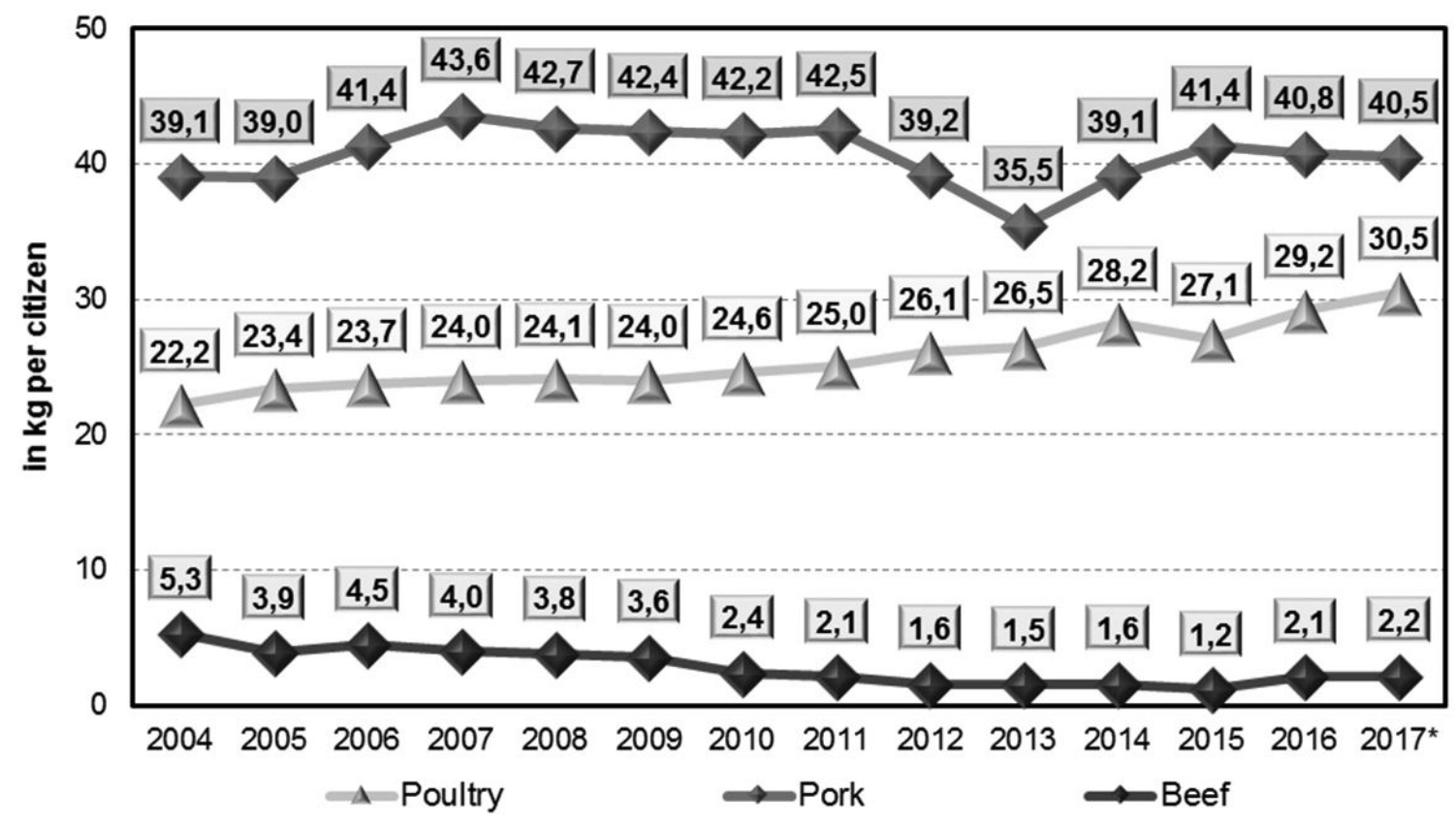

*Estimate of the Institute of Agricultural and Food Economics - National Research Institute.

Figure 2. Meat consumption in Poland

Source: own study based on the data of Statistics Poland (GUS) and the Institute of Agricultural and Food Economics - National Research Institute. 
According to the balance sheet data of Statistics Poland (GUS), in 2016 the consumption of poultry in Poland amounted to $29.2 \mathrm{~kg}$ per capita and was $2.1 \mathrm{~kg}$, i.e. $7.7 \%$, greater than in 2015 . The main factors contributing towards the increase in demand for poultry in 2016 were: growth of production and supply, absolute drop in prices and the cheapening of poultry as compared with red meat, as well as the increase in the population's income (IERiGŻ-PIB et al., 2017).

It is estimated that in the years 2017-2020 the upward trend in poultry consumption per capita in Poland will continue. However, the average rate of growth will likely be slower than in the years 2004 -2016 due to the projected increase in domestic demand for beef and the rising retail prices of poultry. Further increase in poultry consumption will be driven by the rising domestic demand for more expensive species. In 2016, average consumption of geese, ducks and turkeys amounted to $0.21 \mathrm{~kg}$ per person, which constituted a $23.5 \%$ increase in relation to 2015, continuing the trend observed in the preceding years (IERiGŻ-PIB et al., 2018) ${ }^{3}$. In the years 2017-2020, we can expect an increase in household demand for duck, goose and turkey meat. The projected changes in consumption will be determined by the trend consisting in growth in the share of food with significant health benefits in the Polish food market and further increase in the population's income.

\section{CONCLUSIONS}

Other than export, the increase in poultry consumption in Poland after accession to the European Union was one of the main factors determining growth of the domestic poultry industry. In the years 2004-2016 the consumption of poultry increased by nearly $32 \%$, from $22.2 \mathrm{k}$ to $29.2 \mathrm{~kg}$ per capita. In 2017, poultry consumption was estimated to have been $30.5 \mathrm{~kg}$ per capita. The increasing consumption of poultry was a result of its high level of price competitiveness as compared with red meat, dietary properties and change in the dietary habits in favour of low-calorie, low-fat diets. Despite the domestic consumption being high as it is, the level thereof will be on the rise until 2020, further driven by the increased demand for ducks, geese and turkeys, which are considered more expensive types of poultry.

\section{REFERENCES}

1. Dybowski, G. (2016). Rynek mięsa drobiowego [The market for poultry meat]. In: Stańko, S. (ed.) Sytuacja na światowych rynkach mięsa i produktów mleczarskich oraz jej wpływ na rynek krajowy i możliwości jego rozwoju [The situation on the world markets of meat and dairy products and its impact on the domestic market and the possibilities of its development]. Monografie Programu Wieloletniego. IERiGŻ-PIB, Warszawa, pp. 79-104.

2. European Commission (2018). Short-term outlook for EU agricultural markets in 2018 and 2019. Directorate General for Agriculture and Rural Development, Brussels.

3. IERiGŻ-PIB, KOWR, MRiRW (2017). Rynek drobiu. Stan i perspektywy [The poultry market. Status and prospects]. 51. Warszawa.

4. IERiGŻ-PIB, KOWR, MRiRW (2018). Rynek drobiu. Stan i perspektywy [The poultry market. Status and prospects]. 53. Warszawa.

5. Krajowy Ośrodek Wsparcia Rolnictwa - KOWR (2018). Prognoza sytuacji podażowo-popytowej i cenowej na podstawowych rynkach rolnych [Forecast of the supply-demand and price situation on basic agricultural markets]. Retrieved from: www.kowr.gov.pl/analiza/ prognoza-cen-rynkowych-podstawowych-produktowrolno-zywnosciowych.

6. Mieczkowski, M. (2013). Krajowa konsumpcja mięsa drobiowego w latach 2004-2012 [Domestic consumption of poultry meat in 2004-2012]. Biuletyn Informacyjny ARR, 2, pp. 14-19.

\footnotetext{
${ }^{3}$ The results of studies of household budgets, unlike macroeconomic data, refer to industrially processed foodstuffs. They only concern foodstuffs purchased or otherwise obtained by households and intended for consumption within the household. Unlike balance sheet data, they do not take account of the food consumed at restaurants and closed mass catering facilities (at schools, nurseries, hospitals, etc.). Due to the different methodology, data from household budgets are not directly comparable with balance sheet data.
} 
7. Mieczkowski, M. (2015). Konsumpcja mięsa drobiowego w Polsce na tle zmian rynkowych [Consumption of poultry meat in Poland against the background of market changes]. Biuletyn Informacyjny ARR, 2, pp. 14-17.

8. Nowak, M., Trziszka, T. (2010). Zachowania konsumentów na rynku mięsa drobiowego [Consumer behaviour on the poultry meat market]. ŻNTJ, 1 (68), pp. 114-120.

9. Polska Ziemia - Biuletyn informacyjny (2018). Rośnie konsumpcja drobiu w Polsce. Rolnictwo i obszary wiejskie [Poultry consumption in Poland is growing. Agriculture and rural areas]. Retrieved from: www.polska-ziemia.pl.
10. Stańko, S., Mikuła, A. (2017). Tendencje na rynku mięsa drobiowego na świecie i w Polsce w latach 2000-2016 [Trends on the poultry meat market in the world and in Poland in the years 2000-2016]. Zeszyty Naukowe SGGW w Warszawie. Problemy Rolnictwa Światowego, 17 (32), 3, pp. 268-278.

11. Trajer, M. (2018). Rynek mięsa w Polsce i na świecie stan obecny i perspektywy [Meat market in Poland and in the world - current status and prospects]. In: XLIX Dni Przemysłu Mięsnego [49th Meat Industry Days]. Instytut Biotechnologii Przemysłu Rolno-Spożywczego, Warszawa [unpublished].

12. USDA (2018). Livestock and Poultry: World Markets and Trade. USDA Foreign Agricultural Service. 